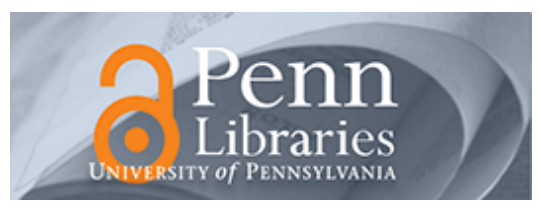

Manuscript Studies

Volume 3

Issue 2 Fall 2018

Article 4

2019

\title{
Illuminated Leaves from an Ethiopic Gospel Book in the Newark Museum and in the Walters Art Museum
}

Jacopo Gnisci

University of Oxford, j.gnisci@live.com

Follow this and additional works at: https://repository.upenn.edu/mss_sims

Part of the Africana Studies Commons, and the Medieval Studies Commons

\section{Recommended Citation}

Gnisci, Jacopo (2019) "Illuminated Leaves from an Ethiopic Gospel Book in the Newark Museum and in the Walters Art Museum," Manuscript Studies: Vol. 3 : Iss. 2 , Article 4.

Available at: https://repository.upenn.edu/mss_sims/vol3/iss2/4 


\title{
Illuminated Leaves from an Ethiopic Gospel Book in the Newark Museum and in the Walters Art Museum
}

\begin{abstract}
This article shows that a group of loose folios kept in two different institutions, the Newark Museum and The Walters Art Museum, originally belonged to an Ethiopic Gospel book dating to the late fourteenth or early fifteenth century. The study examines and analyses the Canon Tables and miniatures that once belonged to this Gospel book to draw conclusions concerning both their features and the broader history of Gospel illumination in medieval Ethiopia.

\section{Keywords}

Ethiopian art, Gospel Illumination, Canon Tables, Evangelists Portraits, Ethiopic Gospel Book, Manuscript studies, codicology
\end{abstract}




\section{MANUSCRIPT STUDIES}

A Journal of the Schoenberg Institute for Manuscript Studies

VOLUME 3, NUMBER 2

(Fall 2018)

Manuscript Studies (ISSN 2381-5329) is published semiannually

by the University of Pennsylvania Press

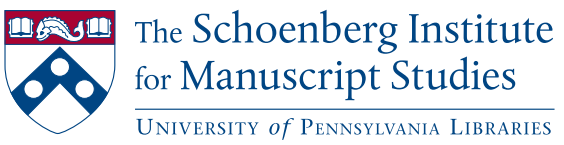




\title{
MANUSCRIPT STUDIES
}

\author{
VOLUME 3, N UMBER 2 \\ (Fall 2018)
}

\section{ISSN 2381-5329}

Copyright ( 2018 University of Pennsylvania Libraries and University of Pennsylvania Press. All rights reserved.

Published by the University of Pennsylvania Press, 3905 Spruce Street, Philadelphia, PA 19104.

Printed in the U.S.A. on acid-free paper.

Manuscript Studies brings together scholarship from around the world and across disciplines related to the study of premodern manuscript books and documents, with a special emphasis on the role of digital technologies in advancing manuscript research. Articles for submission should be prepared according to the Chicago Manual of Style, $16^{\text {th }}$ edition, and follow the style guidelines found at http://mss.pennpress.org.

None of the contents of this journal may be reproduced without prior written consent of the University of Pennsylvania Press. Authorization to photocopy is granted by the University of Pennsylvania Press for libraries or other users registered with Copyright Clearance Center (CCC) Transaction Reporting Service, provided that all required fees are verified with CCC and paid directly to CCC, 222 Rosewood Drive, Danvers, MA 01923. This consent does not extend to other kinds of copying for general distribution, for advertising or promotional purposes, for creating new collective works, for database retrieval, or for resale.

\section{SUBSCRIPTION INFORMATION:}

Single issues: $\$ 30$

Print and online subscriptions: Individuals: \$40; Institutions: \$92; Full-time Students: \$30 International subscribers, please add $\$ 18$ per year for shipping.

Online-only subscriptions: Individuals: $\$ 32$; Institutions: $\$ 80$

Please direct all subscription orders, inquiries, requests for single issues, address changes, and other business communications to Penn Press Journals, 3905 Spruce Street, Philadelphia, PA 19104. Phone: 215-573-1295. Fax: 215-746-3636. Email: journals@pobox.upenn.edu. Prepayment is required. Orders may be charged to MasterCard, Visa, and American Express credit cards. Checks and money orders should be made payable to "University of Pennsylvania Press" and sent to the address printed directly above.

One-year subscriptions are valid January 1 through December 31. Subscriptions received after October 31 in any year become effective the following January 1 . Subscribers joining midyear receive immediately copies of all issues of Manuscript Studies already in print for that year.

Postmaster: send address changes to Penn Press Journals, 3905 Spruce Street, Philadelphia, PA 19104.

Visit Manuscript Studies on the web at mss.pennpress.org. 


\section{MANUSCRIPT STUDIES}

A Journal of the Schoenberg Institute for Manuscript Studies

VOLUME 3 , NUMBER 2

\section{Articles}

Notes of Exchange: Scribal Practices and Vernacular

Religious Scholarship in Early Modern North India

Tyler Williams

Translating Machiavelli's Prince in Early Modern England:

New Manuscript Evidence

Alessandra Petrina

Provenance in the Aggregate: The Social Life of an Arabic

Manuscript Collection in Naples

Paul Love

Illuminated Leaves from an Ethiopic Gospel Book in the

Newark Museum and in the Walters Art Museum

JACOPO GNISCI

Re-Conceptualizing the Poems of the Pearl-Gawain

Manuscript in Line and Color

Maidie Hilmo

\section{Annotations}

A Codicological Assessment of Three Gospel Books with

Sideways-Oriented Illustrations Displayed in the

Metropolitan Museum of Art's Armenia Exhibition

ZsUZsANNA GULÁCSI

A Psalter from Maillezais at Maynooth

Peter J. Lucas and Angela M. Lucas 
iv | Journal for Manuscript Studies

A Dossier of Texts for the Augustinian Hermits of Lucca

Thomas M. IzBicki

Digitizing the University of Pennsylvania's Indic Manuscripts

Benjamin J. Fleming

Reviews

Kathryn M. Rudy. Piety in Pieces: How Medieval Readers

Customized Their Manuscripts

A. R. BennetT

Georgi R. Parpulov. Toward a History of Byzantine Psalters, ca. 850-1350 AD

Barbara Crostini

Corine Schleif and Volker Schier, eds. Manuscripts

Changing Hands

JoHAN OOSTERMAN

495

Nichols, Stephen G. From Parchment to Cyberspace:

Medieval Literature in the Digital Age

BRIDGET WHEARTY

499

List of Manuscripts Cited

505 


\title{
Illuminated Leaves from an Ethiopic Gospel Book in the Newark Museum and in the Walters Art Museum
}

\author{
JACOPO GNISCI \\ Hiob Ludolf Centre for Ethiopian Studies
}

his article Focuses on two series of loose illuminated folios
kept in the collections of the Newark Museum and of the Walters
Art Museum. The Newark Museum, which owns a small but interesting collection of Ethiopian art, has a single leaf with the Ordeal of the Bitter Water on the recto and the Nativity on the verso (fig. 1) as well as a

I would like to thank Lynley A. Herbert, Curator of Rare Books and Manuscripts at the Walters Art Museum, for allowing me to consult material relevant to my research; Christa Clarke, Senior Curator, Arts of Global Africa at the Newark Museum, for giving me access to reproductions of the folios from the Newark Museum and allowing me to work on these; the Hill Museum \& Manuscript Library for access to the microfilms of some of the Gospels discussed in this study; Joshua O'Driscoll, Assistant Curator of Medieval and Renaissance Manuscripts at The Morgan Library and Museum, for allowing me to examine the library's Ethiopic Gospel; Denis Nosnitsin, for giving me access to the manuscripts documented by the Ethio-SPaRe project; Curt Niccum, Professor at the Abilene Christian University for answering my query; Antonella Brita for commenting on a draft; and Michael Gervers for allowing me to use his images. This study was made possible by financial support from the Edith O’Donnell Institute of Art History, the University of Texas at Dallas, and the Beta mașăḩəft project, Hiob Ludolf Centre for Ethiopian Studies, Universität Hamburg. The directors of the two institutes, Richard R. Brettell and Alessandro Bausi, helped me pursue my research aims. I am indebted to many colleagues for sharing their work and ideas with me, including Lucy-Anne Hunt, Elizabeth Mullins, Randall Rosenfeld, and Francesco D’Aiuto. 


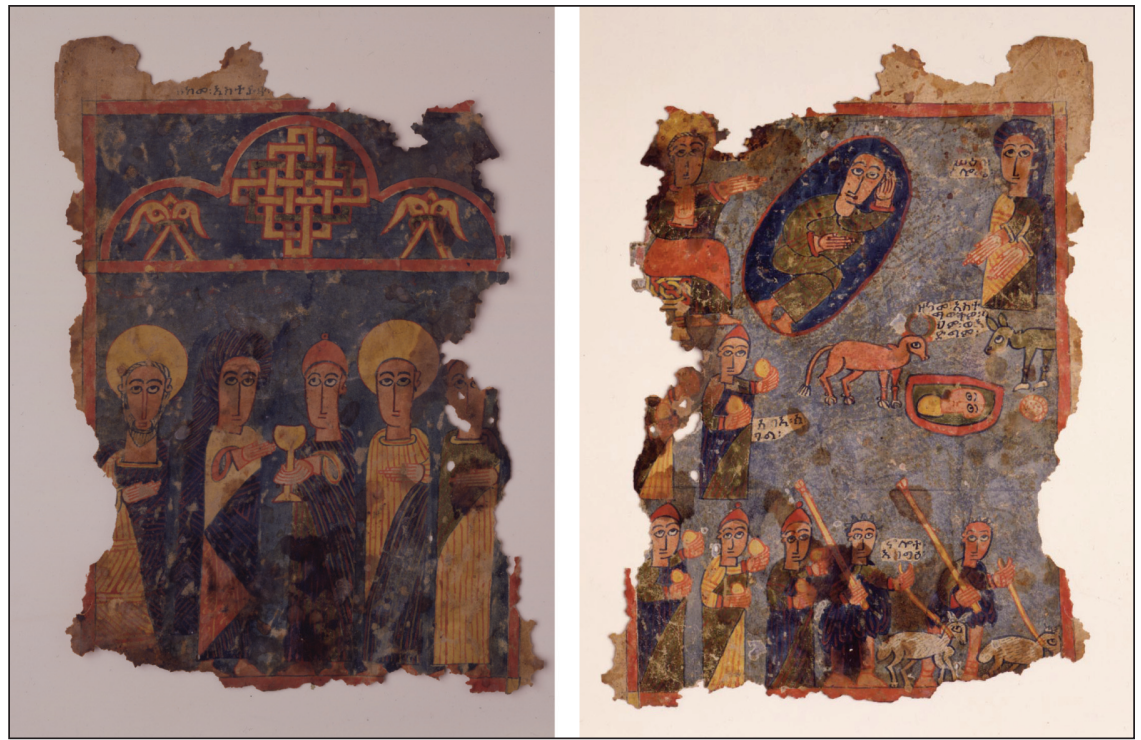

FIGURE 1. Ordeal of the Bitter Water (left). Nativity. Newark, Newark Museum, Coll. $96.46 .1,33 \times 24.1 \mathrm{~cm}$ (right). (C) Newark Museum.

bifolio with the Epistle of Eusebius to Carpianus and two pages of canon tables (fig. 2). These folios come from a private collection, owned by Mr. and Mrs. Knopfelmacher, that was put for sale at the Wright Gallery in New York in the 1990s. ${ }^{1}$ The Knopfelmacher collection included other loose folios that were donated to the Walters Art Museum in 1996. This latter series includes two loose leaves-one decorated with the Evangelist Luke (fig. 3), the other with the Entombment (fig. 4) on the recto and the Resurrected Christ Appearing to Mary Magdalene, John, and Peter on the verso- and a bifolio with four pages of canon tables (fig. 5). As this article shows, these two series of folios must have belonged to an Ethiopic Gospel manuscript produced toward the turn of the fifteenth century (referred to here as NWM).

1 This is based on the information given by Stanislaw Chojnacki, "The Theme of the Bitter Water in Ethiopian Painting," in Aspects of Etbiopian Art from Ancient Axum to the 20th Century, ed. P. B. Henze (London: Jed Press, 1993), 56 n. 15. 
Gnisci: Illuminated Leaves from an Ethiopic Gospel Book


FIGURE 2. Canon tables IX-X and beginning of the Epistle of Eusebius to Carpianus (top). Ending of the Epistle of Eusebius to Carpianus and Canon Tables VI-VIII (bottom). Newark, Newark Museum, Coll. $96.46 .2,34.3 \times 25 \mathrm{~cm}$. (C) Newark Museum. 


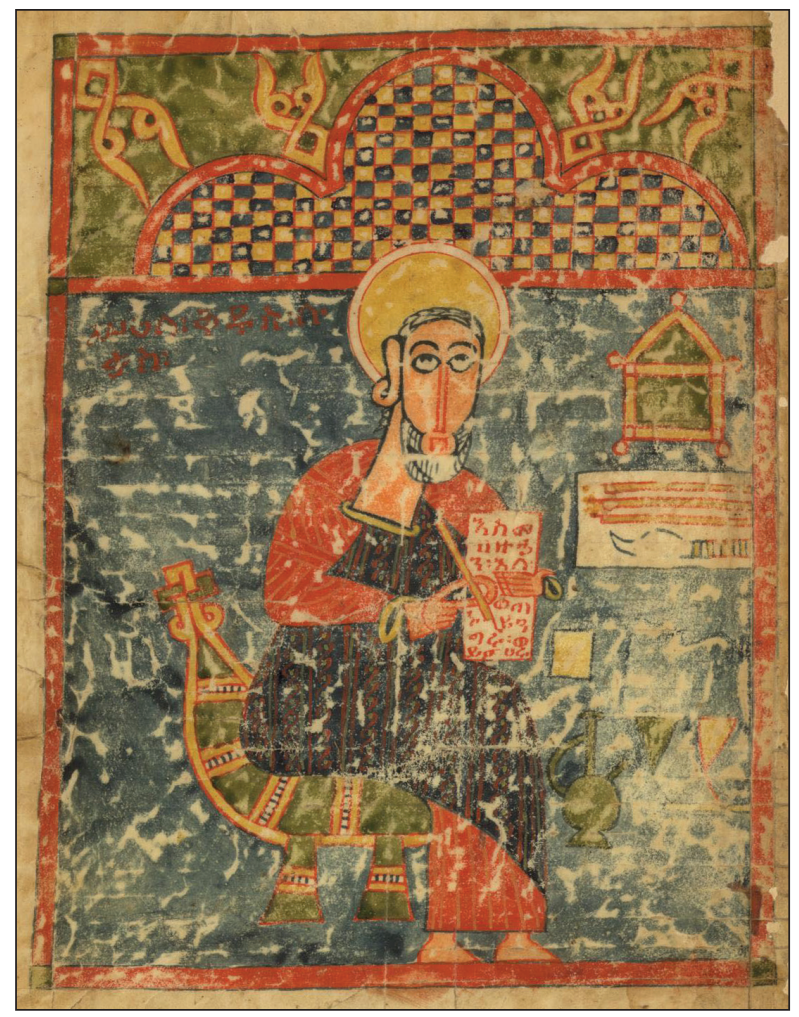

FIGURE 3. The Evangelist Luke. Baltimore, Walters Art Museum, W. $840,35 \times 25.4 \mathrm{~cm}$. (C) The Walters Art Museum.

The bifolio from the Newark Museum (96.46.2) and the four pages in the Walters Art Museum (W.838) form a complete set of canon tables² distributed

2 For a more general discussion of the canon tables outside of Ethiopia, with further bibliography, see Carl Nordenfalk, Die spätantiken Kanontafeln: Kunstgeschichtliche Studien über die eusebianische Evangelien-Konkordanz in den vier ersten Jabrbunderten ibrer Geschichte (Göteborg: Oscar Isacsons Boktryckeri, 1938); Carl Nordenfalk, "The Apostolic Canon Tables," Gazette des Beaux Arts 62 (1963): 17-34; Carl Nordenfalk, "Canon Tables on Papyrus," Dumbarton Oaks Papers 36 (1982): 29-38; Carl Nordenfalk, "The Eusebian Canon-Tables: Some Textual Problems," The Journal of Theological Studies 35, no. 1 (1984): 96-104; May Vieillard, “Les Canons d'évangéliaires de la Basse Antiquité," Cabiers Archéologiques 1 (1945): 113-23; Jules Leroy, "Nouveaux Témoins Des Canons d'Eusèbe Illustrés Selon La Tradition Syri- 


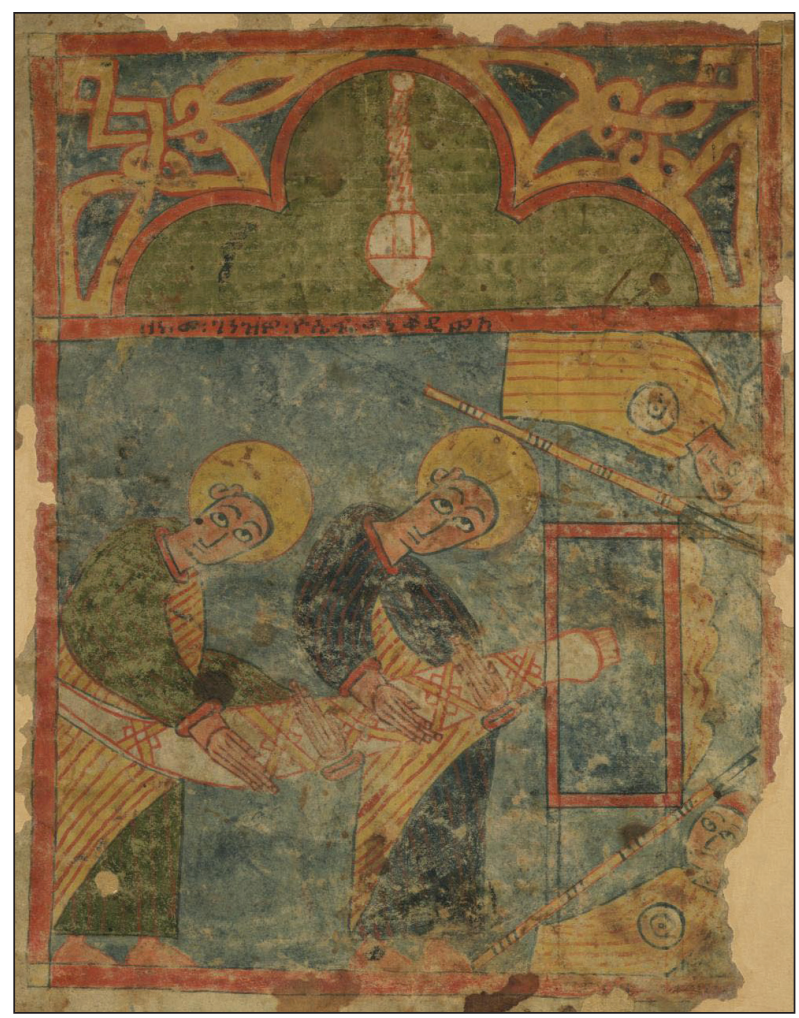

FIGURE 4. The Entombment. Baltimore, Walters Art

Museum, W.839, $38.8 \times 27 \mathrm{~cm}$. (C) The Walters Art Museum.

aque," Cabiers Archéologiques 9 (1957): 117-40; Elisabeth Klemm, "Die Kanontafeln der armenischen Handschrift Cod. 697 im Wiener Mechitaristenkloster,” Zeitschrift für Kunstgeschichte 35 (1972): 69-99; Patrick McGurk, "The Disposition of Numbers in Latin Eusebian Canon Tables," in Philologia Sacra: Biblische und patristische Studien für Hermann J. Frede und Walter Thele zu ibrem siebzigsten Geburtstag, ed. Roger Gryson (Freiburg: Herder, 1993), 242-58; F. D’Aiuto, "Il Libro Dei Vangeli Fra Bisanzio e l'Oriente: riflessioni per l'età Mediobizantina," in Forme e Modelli Della Tradizione Manoscritta Della Bibbia, ed. P. Cherubini (Vatican City: Scuola Vaticana di Paleografia, Diplomatica e Archivistica, 2005), 309-45; R. Amirkhanian, "Les tables de canons arméniennes et le thème iconographique de la Jérusalem céleste," Revue des Études Arméniennes 31 (2008): 181-232; M. Bernabò, “The Miniatures in the Rabbula Gospels: Postscripta to a Recent Book," Dumbarton Oaks Papers 68 (2014): 343-58; W. A. Smith, A Study of the Gospels in Codex Alexandrinus: Codicology, Palaeography, and Scribal Hands (Leiden: Brill, 2014), 139-55, 333-46. 


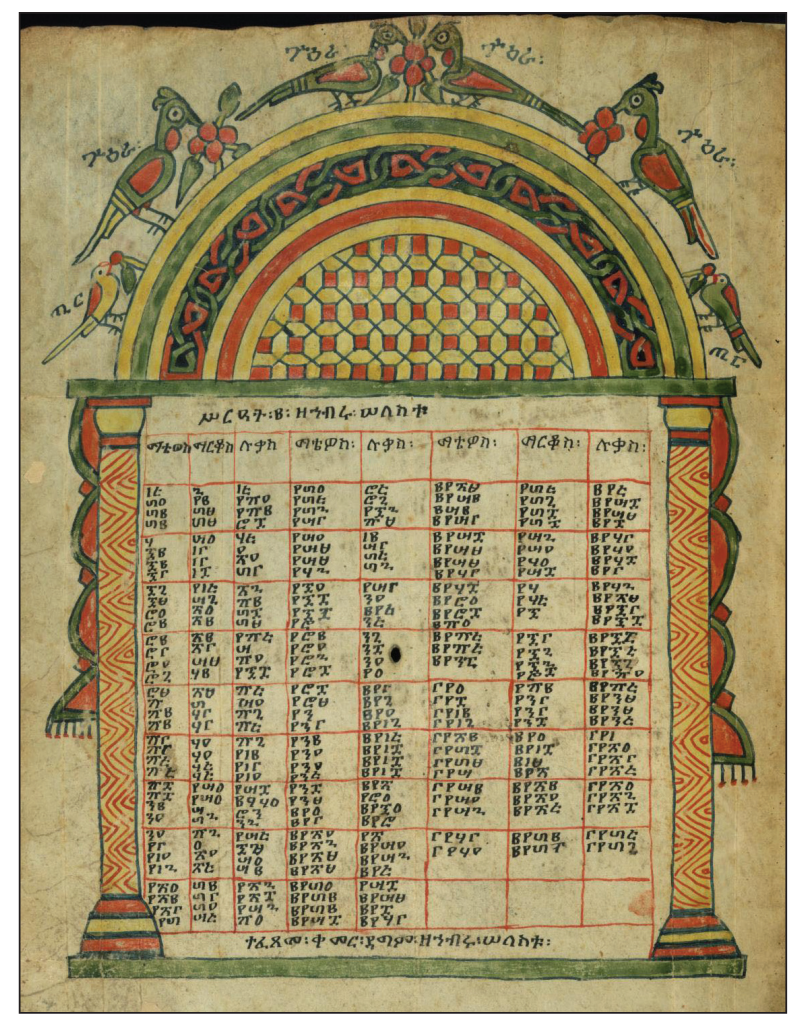

FIGURE 5. Canon Table II. Baltimore, Walters Art Museum, W. $838,35 \times 25.5 \mathrm{~cm}$. (C) The Walters Art Museum.

over six pages and preceded by the Epistle of Eusebius to Carpianus ${ }^{3}$ on two pages (see table 1). This arrangement of the Eusebian system is unusual, for the canon tables in Ethiopic Gospels are generally distributed over eight or

3 On the Epistle, see H. H. Oliver, "The Epistle of Eusebius to Carpianus: Textual Tradition and Translation," Novum Testamentum 3, no. 1 (1959): 138-45; M. R. Crawford, "Ammonius of Alexandria, Eusebius of Caesarea and the Origins of Gospels Scholarship," New Testament Studies 61, no. 1 (2015): 1-29. 
seven pages preceded respectively by two or three pages with the Eusebian letter, in such a way that the total number of pages is always ten $(8+2$ or $7+3) .{ }^{4}$ Both arrangements have a long-standing tradition in Ethiopia, being found in Gospels from the Christian Aksumite period. The earliest witness to the first arrangement $(8+2)$ is Gärima III (AG-III), which has been dated to circa AD 330-650 by several carbon-14 tests. The earliest witness to the second arrangement $(7+3)$ is Gärima I (AG-I), which has been dated to circa AD 530-660 using the same method. ${ }^{5}$ Aside from these two Gospels,

4 For further observations about the canon tables in Ethiopia, see J. Leroy, "Recherches sur la tradition iconographique des canons d'Eusèbe en Éthiopie," Cabiers Archéologiques 12 (1962): 173-204; Nordenfalk, The Eusebian Canon-Tables, 99-101; R. Zuurmond, ed., Novum Testamentum Aethiopice: The Synoptic Gospels, Äthiopistische Forschungen 27 (Stuttgart: Franz Steiner Verlag, 1989), Part I, 20-21; V. Popovic, "Sur l'origine de l'évangéliaire latin de la British Library, Harley 1775," Comptes rendus des séances de l'Académie des Inscriptions et BellesLettres 134, no. 3 (1990): 709-35; M. E. Heldman, “Canon Tables,” Encyclopaedia Aethiopica, ed. S. Uhlig et al., 5 vols. (Wiesbaden: Harrassowitz, 2003), 1:680-82; M. E. Heldman, Miniatures of the Gospels of Princess Zir Gānēlā: An Ethiopic Manuscript Dated AD 1400/01 (PhD diss., Washington University, 1972), 94-108, though most conclusions are no longer tenable; A. Bausi, "Some Short Remarks on the Canon Tables in Ethiopic Manuscripts," in Scritti in onore di Clelia Sarnelli Cerqua, ed. C. Baffioni, Studi Magrebini 26 (Naples: Università degli Studi di Napoli "L'Orientale," 2004), 45-67; C. Lepage and J. Mercier, "Un tétraévangile illustré éthiopien à cycle long du XVe siècle-Codicologie et iconographie," Cabiers Archéologiques 54 (2012): 99-174; J. S. McKenzie and F. Watson, The Garima Gospels: Early Illuminated Gospel Books from Etbiopia (Oxford: Manar Al-Athar, 2016), with additional bibliography. The predominant opinion is that the Ethiopian canon tables, like the Ethiopic text of the Gospels, are based on Greek models. In the Ethiopian tradition, the canon tables

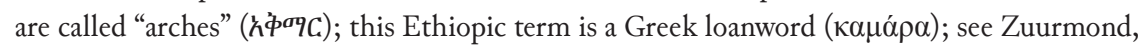
Novum Testamentum, Part I, n. 29; though cf. W. Leslau, Comparative Dictionary of Gecez (Classical Ethiopic) (Wiesbaden: Harrassowitz, 1987), 432; and Bausi, Remarks on the Canon Tables, 55-56. There are no apparent connections with the developments taking place in Copto-Arabic Gospel books of the Mamluk period; see for instance the canon tables in L.-A. Hunt, "A Christian Arab Gospel Book: Cairo, Coptic Museum MS Bibl. 90 in Its Mamluk Context," Mamluk Studies Review 13, no. 2 (2009): 105-32.

5 On the Gärima Gospels, see J. Leroy, "L'évangéliaire éthiopien du couvent d'Abba Garima et ses attaches avec l'ancien art chrétien de Syrie," Cabiers Archéologiques 11 (1960): 131-43; J. Leroy, "Un nouvel évangéliaire éthiopien illustré du monastère d'Abba Garima," in Syntbronon: Art et Archéologie de la fin de l'Antiquité et du Moyen Age. Recueil d'études par André Grabar et un groupe de ses disciples, ed. A. Grabar (Paris: C. Klincksieck, 1968), 75-87. On their date, see M. E. Heldman, “The Heritage of Late Antiquity," in African Zion: The Sacred Art of 
TABLE 1. A reconstruction of the original page sequence.

\begin{tabular}{|c|c|c|c|c|}
\hline Folio & Content & Lines & & Notes \\
\hline $\begin{array}{l}\text { Newark } \\
96.46 .2 \text {, f. } 1 \mathrm{r}\end{array}$ & $\begin{array}{l}\text { The Epistle of Eusebius } \\
\text { to Carpianus }\end{array}$ & 30 & & \\
\hline $\begin{array}{l}\text { Newark } \\
96.46 .2, \text { f. } 1 \mathrm{v}\end{array}$ & $\begin{array}{l}\text { The Epistle of Eusebius } \\
\text { to Carpianus }\end{array}$ & 20 & & $\begin{array}{l}\text { Stichometry of Gospels } \\
\text { and chapter count (?) at } \\
\text { end of page }\end{array}$ \\
\hline & Canon & Lines & Grid & \\
\hline W.838, f. 1r & $\mathrm{I}^{\mathrm{Mt} \text { Mk Lk Jn }} \quad \mathrm{I}^{\mathrm{Mt} \text { Mk Lk Jn }}$ & $I^{69}$ & $10 \times 8$ & $\begin{array}{l}\text { I missing lines, several } \\
\text { wrong numbers }\end{array}$ \\
\hline W.838, f. 1v & $\mathrm{II}^{\mathrm{Mt} M \mathrm{Lk}} \quad \mathrm{II}^{\mathrm{Mt} \mathrm{Lk}} \quad \mathrm{II}^{\mathrm{Mt} \mathrm{Mk} L \mathrm{~L}}$ & $\mathrm{II}^{101}$ & $10 \times 8$ & $\begin{array}{l}\text { II missing one column } \\
(\mathrm{Mk}) \text {, missing lines, } \\
\text { several wrong numbers }\end{array}$ \\
\hline W.838, f. 2r & $\mathrm{III}^{\mathrm{Mt} \mathrm{Lk} J \mathrm{n}} \quad \mathrm{IV}^{\mathrm{Mt} J \mathrm{n}}$ & $\mathrm{III}^{21} \quad \mathrm{IV}^{25}$ & $10 \times 7$ & $\begin{array}{l}\text { III several wrong } \\
\text { numbers; } \\
\text { IV missing one column } \\
(\mathrm{Mk}) \text {, missing line, } \\
\text { several wrong numbers }\end{array}$ \\
\hline W.838, f. 2v & $\mathrm{V}^{\mathrm{Mt} \mathrm{Lk}} \quad \mathrm{V}^{\mathrm{Mt} \mathrm{Lk}} \quad \mathrm{V}^{\mathrm{Mt} \mathrm{Lk}}$ & $\mathrm{V}^{76}$ & $10 \times 7$ & $\begin{array}{l}\mathrm{V} \text { missing lines, several } \\
\text { wrong numbers }\end{array}$ \\
\hline $\begin{array}{l}\text { Newark } \\
96.46 .2 \text {, f. } 2 \mathrm{r}\end{array}$ & $\begin{array}{ll}\text { VI }^{\mathrm{Mt} \mathrm{Mk}} \quad \mathrm{VI}^{\mathrm{Mt} M \mathrm{k}} & \mathrm{VII}^{\mathrm{Mt} \mathrm{Jn}} \\
\mathrm{VIII}^{\mathrm{Lk} M k} & \end{array}$ & $\begin{array}{l}\mathrm{VI}^{46} \mathrm{VII}^{8} \\
\mathrm{VIII}^{13}\end{array}$ & $11 \times 8$ & $\begin{array}{l}\text { VI missing lines; } \\
\text { VII one extra number } \\
\text { (70), wrong numbers; } \\
\text { VIII missing one number, } \\
\text { several wrong numbers }\end{array}$ \\
\hline $\begin{array}{l}\text { Newark } \\
96.46 .2 \text {, f. } 2 \mathrm{v}\end{array}$ & 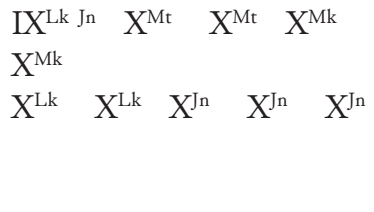 & $\begin{array}{ll}\mathrm{IX}^{19} & \mathrm{X}_{1}^{57} \\
\mathrm{X}_{2}^{15} & \mathrm{X}_{3}^{61} \\
\mathrm{X}_{4}^{76} & \end{array}$ & $12 \times 11$ & $\begin{array}{l}\text { IX several wrong } \\
\text { numbers; } \\
\mathrm{X}_{1} \mathrm{X}_{2}, \mathrm{X}_{3}, \mathrm{X}_{4} \text {, missing } \\
\text { lines, several wrong } \\
\text { numbers }\end{array}$ \\
\hline
\end{tabular}

Ethiopia, ed. R. Grierson (New Haven: Yale University Press, 1993), 129-30; J. Mercier, "La peinture éthiopienne à l'époque axoumite et au XVIIIe siècle," Comptes rendus des séances de l'Académie des Inscriptions et Belles-Lettres 144, no. 1 (2000): 36-45; R. Zuurmond and R. C. Niccum, "The Ethiopic Version of the New Testament," in The Text of the New Testament in Contemporary Research: Essays on the Status Quaestionis, 2nd ed., ed. B. D. Ehrman and M. W. Holmes (Leiden: Brill, 2012), 231-52, with further bibliography. 
surviving examples of canon tables in Ethiopia are found in manuscripts dating from about the late thirteenth century onward. ${ }^{6}$ The $7+3$ layout is found in most surviving manuscripts of the fourteenth and early fifteenth centuries.

As illustrated in the table, the unorthodox distribution of the canon tables over six pages in NWM results in Canons VI to X being compressed into two pages, whereas they usually occupy four pages when preceded by the Epistle of Eusebius to Carpianus in two pages, or three pages when the letter takes up three pages. ${ }^{7}$ The canons also present numerous errors and omissions. For instance, in Canon II (see fig. 5) - which lists the parallels between Matthew, Mark, and Luke-the Eusebian numbers ${ }^{8}$ are inserted in an $8 \times 9$ instead of a $9 \times 9$ grid. Thus, the fifth column with the numbers for Mark is missing, though interestingly the numbering resumes in the seventh column as if the fifth column had not been omitted. The same phenomenon occurs in Canon IV, which should list the passages for Matthew, Mark, and John, but the column with Mark's numbers is missing.

Many of the numbers in the canons are wrong. For instance, in Canon III there are twenty-one lines, which is the correct number in the Ethiopian tradition, and the numbers in Matthew's column are in the right sequence. However, the numbers in the sequences of Luke and John are mostly wrong,

6 For several examples, see J. Leroy, Canons d'Eusèbe en Éthiopie. The Eusebian sections are marked on the text of some earlier manuscripts indicating that they originally included canon tables; see Zuurmond, Novum Testamentum, Part II, 53-54. It is difficult to suggest a precise date for the canon tables included in the Gospel of Däbrä Libanos, mentioned by C. Conti Rossini, "L'Evangelo d'oro di Dabra Libanos," Rendiconti della Reale Accademia dei Lincei, Classe di scienze morali, storiche e filologiche 5, no. 10 (1901): 182, though it seems possible that they predate the ascent of the Solomonic dynasty. On these canon tables, see A. Bausi, "Su alcuni manoscritti presso comunità monastiche dell'Eritrea: Parte terza," Rassegna di Studi Etiopici 41 (1997): 13-23.

7 While this observation is true for most manuscripts, variations do occur. For example, in the Gospel manuscript in the Bibliothèque nationale de France (Éthiopien 32, ca. 13441371), Canon VI begins on the same page of Canon V (fol. 5r) and ends on the following page (fol. $5 \mathrm{v})$.

8 On the use of this definition over "Ammonian sections," see Crawford, Ammonius of Alexandria, 23-25, with further reading. 
with the numeral 2 frequently mistaken for a 9 throughout the canon tables. ${ }^{9}$ A systematic comparison of these errors has yet to be undertaken, though it may yield information on the relationship between different groups of canon tables, especially when distinctive sequences of errors are present. Thus, for instance, the presence of similar sequences of errors in the canon tables of AG-III and a later Gospel kept in the same monastery (AG-II), may indicate that the former depends on the latter. Evidently, the presence of such errors in an early witness such as AG-III raises the question if the canon tables were ever really used as a cross-referencing system in Ethiopia. ${ }^{10}$

The Ethiopic version of the Epistle of Eusebius to Carpianus, like the canon tables and the Gospels, derives from a Greek text. ${ }^{11}$ The text of the

9 As C. Lepage, "Reconstitution d'un cycle protobyzantin à partir des miniatures de deux manuscrits éthiopiens du XIVe siècle,” Cahiers Archéologiques 35 (1987): 159-96, esp. 160, signals, such errors are frequently encountered in manuscripts from this period. The numerals 1 and 4, as well as 6 and 7, are also frequently interchanged. This is because the signs used for each of these pairs are very similar and cannot always be easily distinguished.

10 This question has been recently raised also in McKenzie and Watson, The Garima Gospels, 169. Although further research is needed before an acceptable answer can be provided to this issue, it is worth making a few general observations. Ethiopia is not the only context for which there is evidence of a lack of familiarity with the content of the Eusebian apparatus. For instance, T. O'Loughlin, "Harmonizing the Truth: Eusebius and the Problem of the Four Gospels," Traditio 65 (2010): 1-29, esp. 13-29, has recently drawn attention to the fact that some Hiberno-Saxon Gospels, such as the Book of Kells (Dublin, Trinity College Library, 58), which does not include the Eusebian sections in its margins, bear evidence of a "lack of understanding" of the function and content of the Eusebian apparatus. Yet, as E. Mullins, "The Eusebian Canon Tables and Hiberno-Latin Exegesis: The Case of Vienna, Österreichische Nationalbibliothek, Lat. 940," Sacris Erudiri 53 (2014): 323-43, argues, this does not preclude an interest in, or appreciation of, their function. A similar point has been more recently made by M. R. Crawford, "Scholarly Practices: The Eusebian Canon Tables in the Hiberno-Latin Tradition," in Producing Christian Culture: Medieval Exegesis and Its Interpretative Genres, ed. Giles E. M. Gasper, F. Watson, and M. R. Crawford (London: Routledge, 2017), 65-88.

11 For some observations, see Zuurmond, Novum Testamentum, Part I, 19-20, with additional references. The Ge'ez text was first discussed and translated in English by R. W. Cowley, "New Testament Introduction in the Andemta Commentary Tradition," Ostkircbliche Studien 26 (1977): 144-92, esp. 162 -164. A more recent text-critical edition is found in A. Bausi, "La versione etiopica della Epistola di Eusebio a Carpiano," in Aetbiopia Fortitudo ejus. Studi in onore di Monsignor Osvaldo Raineri in occasione del suo $80^{\circ}$ compleanno, ed. R. Zarzeczny, Orientalia Christiana Analecta 298 (Rome: Pontificio Istituto Orientale, 2015), 107-35. 
Epistle in NWM is not too dissimilar from that found in the Gärima Gospels (see fig. 2), though it features alterations, omissions, and additions that are found in later manuscripts of the thirteenth century onward. ${ }^{12}$ Two counts, each inserted in a rectangular frame, are found at the bottom of the second page of the Epistle next to a Chi Rho sign (see fig. 2, bottom). One lists the number of stichoi in each Gospel (Mt. 2700; Mk. 1700; Lk. 2800; Jn. 2700). ${ }^{13}$ It is less clear what the second set of numbers indicates (Mt. 115; Mk. 55; Lk. 40; Jn. 58). ${ }^{14}$ While the introductory matter to Ethiopic Gospels often includes the stichometry, it is unusual to find this data placed at the end of the Letter of Eusebius to Carpianus, though a similar solution is also adopted in the Zir Ganela Gospels (ZG). ${ }^{15}$ It is possible that such a solution was adopted in later manuscripts to synthetize the prefatory matter included at the beginning of the Gospels. ${ }^{16}$

Both the Epistle to Carpianus and the canon tables in NWM are placed under brightly colored and highly stylized arches, a layout attested already in the two Gärima Gospels. Stylistically, however, the simplified arches and columns recall examples from manuscripts belonging to the second half of the fourteenth or early fifteenth century, such as those seen in the Gospels of Boru Śllase (BSL), ${ }^{17}$ of Däbrä Tä'amina (DTM), ${ }^{18}$ and of the Bibliothèque

The Greek version of the Eusebian system in the 28th edition of the Nestle-Aland Novum Testamentum Graece is on pp. $45^{*}-50^{*}$.

12 Cf. Bausi, Epistola di Eusebio a Carpiano, text $\mathrm{E}^{1832}$.

13 Cowley, New Testament Introduction, 160; Zuurmond, Novum Testamentum, Part I, 25-26.

14 According to Curt Niccum, it is possible that the numbers are corrupt and indicate the chapters in the four Gospels (personal communication, 27 January 2017).

15 The Morgan Library \& Museum, MS m.828, 1400/1401. On this manuscript, see Heldman, The Gospels of Princess Zir Gānēlā; P. W. Skehan, "An Illuminated Gospel Book in Ethiopic," in Studies in Art and Literature for Belle da Costa Greene, ed. D. Miner (Princeton, NJ: Princeton University Press, 1954), 350-57; and E. Balicka-Witakowska, La Crucifixion sans Crucifié dans l'art éthiopien: Recherches sur la survie de l'iconograpbie chrétienne de l'Antiquité tardive, Bibliotheca nubica et aethiopica 4 (Warsaw: Zaś Pan, 1997), esp. 130-31.

16 On the introductory content, see Zuurmond, Novum Testamentum, 7-31, with further reading.

17 On this manuscript, see also Balicka-Witakowska, Crucifixion, esp. 128-29, with further bibliography.

18 The manuscript was photographed by Michael Gervers and is mentioned in A. Bausi and E. Balicka-Witakowska, "Däbrä Tä’amina,” Encyclopaedia Aetbiopica, ed. S. Uhlig et al., 5 vols. 
nationale de France (BNF), ${ }^{19}$ as well as in a manuscript from a private collection documented by Balicka-Witakowska ${ }^{20}$ in which several columns are decorated with a zigzag pattern similar to the one used in all the pages of NWM. It is therefore likely that also the Eusebian apparatus in NWM was produced toward the turn of the fifteenth century.

The space around the arches, as is generally the case in fourteenth- and early fifteenth-century Ethiopian canon tables, is densely populated by birds. For instance, on the first page of the Epistle to Carpianus there are


the floral elements that sprout from the outer band of the arch. ${ }^{21}$ Peacocks are consistently placed only on the first page of the Epistle to Carpianus in Ethiopic Gospels of the late thirteenth to the mid-fifteenth centuries that adopt the 7+3 layout. Peacocks also appear in the two early Gärima Gospels, though significantly in AG-III, which has the $8+2$ layout, they appear on the second page of the Epistle to Carpianus, whereas in AG-I, which has the $7+3$ layout, they are placed only on the first page. This suggests that the later Gospels with the 7+3 layout, in which the peacocks are placed only on the first page of the Epistle to Carpianus, may ultimately depend on the same model used for AG-I.22

In Ethiopic Gospels of the fourteenth and fifteenth centuries, the birds

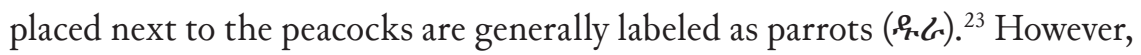
two pairs of small $\mathrm{n} . \mathrm{C}$. do appear in the first page of the Epistle to Carpianus

(Wiesbaden: Harrassowitz, 2005), 2:48-49.

19 On this manuscript, see Balicka-Witakowska, Crucifixion, 125-26; and J. Gnisci, "Picturing the Liturgy: Notes on the Iconography of the Holy Women at the Tomb in Fourteenthand Early-Fifteenth-Century Ethiopian Manuscript Illumination," Bulletin of the School of Oriental and African Studies 78, no. 3 (2015): 568, with further bibliography.

20 See EBW-2006.006:001 to EBW-2006.006:007 in the DEEDS database.

21 On these terms in the Ethiopic tradition, see Bausi, Remarks on the Canon Tables, esp. 66-67; Bausi, Su alcuni manoscritti, 17 n. 10.

22 This is a feature found also in a number of early Greek and Armenian Gospels, as noted in Lepage, Reconstitution d'un cycle protobyzantin, 160; for some examples, see S. Der Nersessian, "The Date of the Initial Miniatures of the Etchmiadzin Gospel," The Art Bulletin 15, no. 4 (1993): 327-60, figs. 13-16; and K. Weitzmann, Die byzantinische Buchmalerei des 9.und 10. Jabrbunderts (Berlin: Gebr. Mann, 1935), pl. 17.

23 Bausi, Remarks on the Canon Tables, 65. 
in DTM together with two medium-size birds (hєQ. $\rho) .{ }^{24}$ Although the text of the epistle in NWM does not follow that in DTM, which also uses three rather than two pages for the Eusebian letter, it is interesting to note that they do have some similar features and spell Carpianus ( $\boldsymbol{\phi} \dot{s} \boldsymbol{C}, 99 \boldsymbol{i})$ in the same uncommon way. ${ }^{25}$

The next three openings of NWM have the same arrangement of birds on both facing pages. Thus, for instance, on the last page of the Epistle to Carpianus as well as on Canon I, two pairs of four of climb from opposite sides toward the top of the arch. Matching arrangements of birds are also found in the page spread of the canon tables in BS. ${ }^{26}$ However, while the names used to identify the birds are the same as in NWM, they appear in a different sequence. The last page of canon tables in BS is juxtaposed with a tempietto (fol. $8 \mathrm{r}$ ), and it is possible that Canon X in NWM originally faced a similarly illustrated page. ${ }^{27}$ Together with the shoots and floral elements that are placed around the arches, the groups of birds in the NWM canon tables evoke, as captions in other manuscripts tell us, ${ }^{28}$ the garden of paradise.

While there is no doubt that the pages with the Epistle to Carpianus and the canon tables came from the same manuscript, it is not possible to assert this so confidently for the other folios discussed hereafter. While

24 Bausi, Remarks on the Canon Tables, 63.

25 On the spelling, see Zuurmond, Novum Testamentum, Part I, 20; cf. also Bausi, Epistola di Eusebio a Carpiano; on the form of $\boldsymbol{k}$, see S. Uhlig, Ätbiopische Paläographie, Äthiopistische Forschungen 22 (Stuttgart: Franz Steiner, 1988), 384; S. Uhlig, Introduction to Ethiopian Palaeography, Äthiopistische Forschungen 28 (Stuttgart: Franz Steiner, 1990), 60.

26 And in numerous other manuscripts from this period, see observations by Leroy, Reconstitution d'un cycle protobyzantin, 160 n. 15, with further references to other earlier manuscripts. 27 On the Tempietto, see Der Nersessian, Etchmiadzin Gospel, 341-45, figs. 17-18; P. A. Underwood, "The Fountain of Life in Manuscripts of the Gospels," Dumbarton Oaks Papers 5 (1950), 41-138; and J. McKenzie, The Architecture of Alexandria and Egypt: c. 300 BC to AD 700 (New Haven: Yale University Press, 2007), 367-70. For a more detailed discussion of this motif in Ethiopian art, with the complete bibliography, see my forthcoming article "An Ethiopian Miniature of the Tempietto and Its Relatives.”

28 E.g., ZG, fol. $5 \mathrm{v}$. 
their provenance and similar size support this possibility, ${ }^{29}$ the handwriting of the canon tables seems different from that which appears above the miniatures. However, if the artist and scribe were not the same person, then it is possible to explain this discrepancy by suggesting that the former was responsible for the captions above the images or that a third person was involved in their production.

Regardless of whether this was the case, it seems likely that the stained and damaged leaf with the Nativity and the Ordeal of the Bitter Water in the Newark Museum and the folio with the Entombment and the Resurrected Christ in the Walters Art Museum, which are closely related to each other and the Eusebian apparatus in stylistic terms, came from a Gospel manuscript, for it is in Gospel manuscripts that such scenes are generally found..$^{30}$ There is, of course, little question that the folio with the Evangelist Luke came from a Gospel manuscript.

The style of the miniatures points toward a similar date to the one that has been suggested above for the Epistle to Carpianus and canon tablesnamely, the turn of the fifteenth century. The figures in the Newark Museum and the Walters Art Museum leaves-with their elongated ovalshaped faces and upturned eyes-are stylistically very close to the figures that appear in BSL and DTM. This observation becomes more significant when we consider that the style of the arches placed above the Epistle to Carpianus and the canon tables in these latter two manuscripts can also be linked, as shown above, with NWM.

It is also worth mentioning a loose leaf in the collection of the Getty Museum (GTM) with the Evangelist John, ${ }^{31}$ which is very close, in terms of

29 W.839 is slightly larger than all the other folios, but the layout of the image $(28.2 \times 22.2$ $\mathrm{cm})$ is almost identical to that of W.840 $(29 \times 22.2 \mathrm{~cm})$. It is quite possible that some of the other folios were trimmed; this certainly appears to be the case for the upper margin of the canon tables.

30 For an overview with further literature, see E. Balicka-Witakowska, "Gospel illustration," Encyclopaedia Aethiopica, 2:859-60, with more references.

31 Coll. no. MS 89, $33.7 \times 23.3 \mathrm{~cm}$, turn of the fifteenth century (?). On the Evangelists in Ethiopian art, see Heldman, The Gospels of Princess Zir Gānèlā, 109-17; Heldman, "Evangelists in art," in Encyclopaedia Aethiopica, 2:461-63, with further bibliography. A systematic study of the Evangelist portraits in Ethiopic Gospels is a desideratum. When decorated with 
style and iconography, to the evangelist portrait in NWM. Two even closer parallels to the portrait of Luke in NWM (see fig. 3) are found in DTM and BSL (figs. 6-7). ${ }^{32}$ With regard to their style, in all three examples Luke has an elongated face; almond-shaped eyes; a long, straight nose; and a rectangular-shaped mouth. As for their iconography, all three portraits show Luke sitting on a chair in which the vertical lines are interrupted by decorative horizontal lines and which has two visible legs, a cross-shaped finial, and a rounded back. Likewise, in all three cases Luke sits in the same position; wears the same attire; holds the beginning of his Gospel with his left hand, which has a hook-shaped thumb sticking out; holds the reed with his right hand with the index and thumb forming a loop around it; and has white hair and a white beard streaked with black lines.

There are some differences between the three miniatures. In DTM and NWM, Luke has a rimmed halo and his eyes turn upward, whereas in BSL

paintings, the Ethiopic Gospels—as in Greek, Latin, Armenian, Georgian, Syriac, and CoptoArabic manuscripts-frequently include portraits of seated or standing Evangelists placed on the verso of the folio that precedes the beginning of their Gospel. For a more general introduction to the Evangelist portraits in Christian manuscript illumination, the classic study is still that by A. M. Friend, "The Portraits of the Evangelists in Greek and Latin Manuscripts," Art Studies 5 (1927): 115-47; A. M. Friend, "The Portraits of the Evangelists in Greek and Latin Manuscripts," Art Studies 7 (1929): 3-29. On the subject, see also E. Rosenbaum, "The Evangelist Portraits of the Ada School and Their Models," The Art Bulletin 38, no. 2 (1956): 81-90; H. Buchthal, "A Byzantine Miniature of the Fourth Evangelist and Its Relatives," Dumbarton Oaks Papers 15 (1961): 127-39; H. Hunger and K. Wessel, "Evangelisten," in Reallexicon zur byzantinischen Kunst, ed. Klaus Wessel (Stuttgart: Anton Hiersemann, 1971), 2:452-507; R. P. Bergman, "Portraits of the Evangelists in Greek Manuscripts," in Illuminated Greek Manuscripts from American Collections, ed. Gary Vikan (Princeton, NJ: Princeton University Press, 1973), 44-49; R. Rosenfeld, “The Prophets and Apostles Write: Images and the Medieval Understanding of Writing," Scripta Mediterranea 12-13 (1991): 53-96; and R. S. Nelson, “A Thirteenth-Century Byzantine Miniature in the Vatican Library," Gesta 20, no. 1 (1981): 213-22.

32 Two more distant relatives are found in the Gospel manuscripts of Maryam Tənśa'e, late fourteenth or early fifteenth century (folios unnumbered) (see Balicka-Witakowska, Crucifixion, 132, for a description and further bibliography) and of Qärsäbär Mika'el, fifteenth century (?), fol. 94v, (see D. Nosnitsin, Churches and Monasteries of Tagray: A Survey of Manuscript Collections, Supplement to Aethiopica 1 [Wiesbaden: Harrassowitz, 2013], 55). 


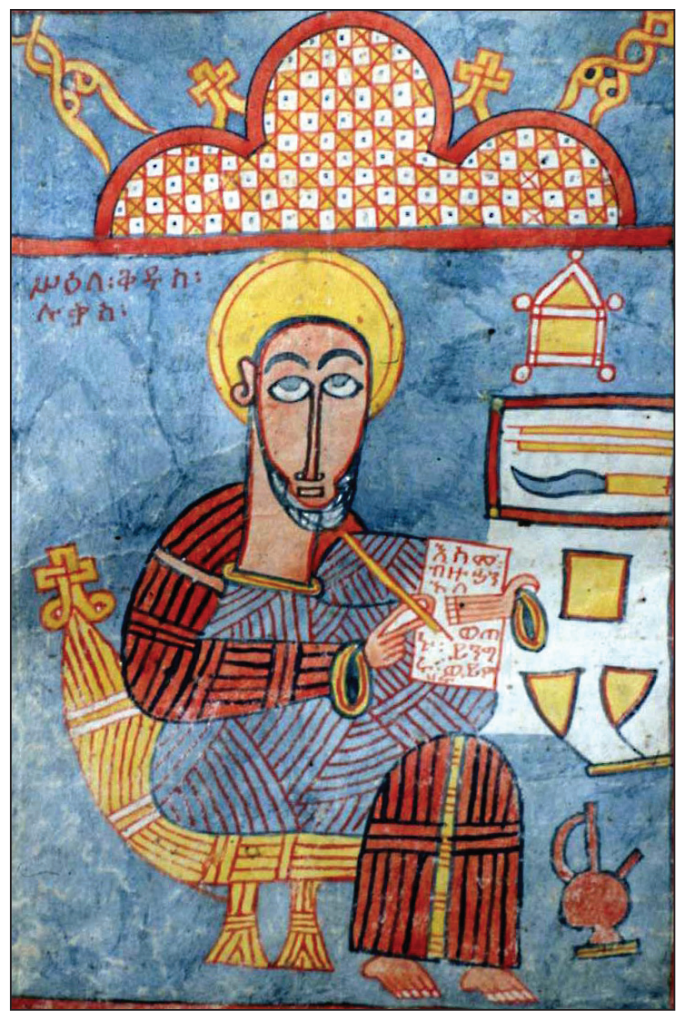

FIGU RE 6. The Evangelist Luke. Gospel book from the monastery of Däbrä Tä'amina in Təgray, $34.5 \times$ $21.5 \mathrm{~cm}$. (C) Michael Gervers.

the halo has no ornaments and he gazes back at the viewer. A further difference between BSL, DTM, and NWM is that in the latter two manuscripts, Luke's left sleeve cuff has been painted like a loop sticking out awkwardly-a detail also found in the Ordeal of the Bitter Water in NWM (see fig. 1, left). Lastly, DTM is the only manuscript in which Luke's toenails have been depicted. However, the similarities outweigh these differences, and there can be little doubt that the three miniatures had a common ancestor. This impression is strengthened by looking at the other elements present in the three miniatures. 
Gnisci: Illuminated Leaves from an Ethiopic Gospel Book

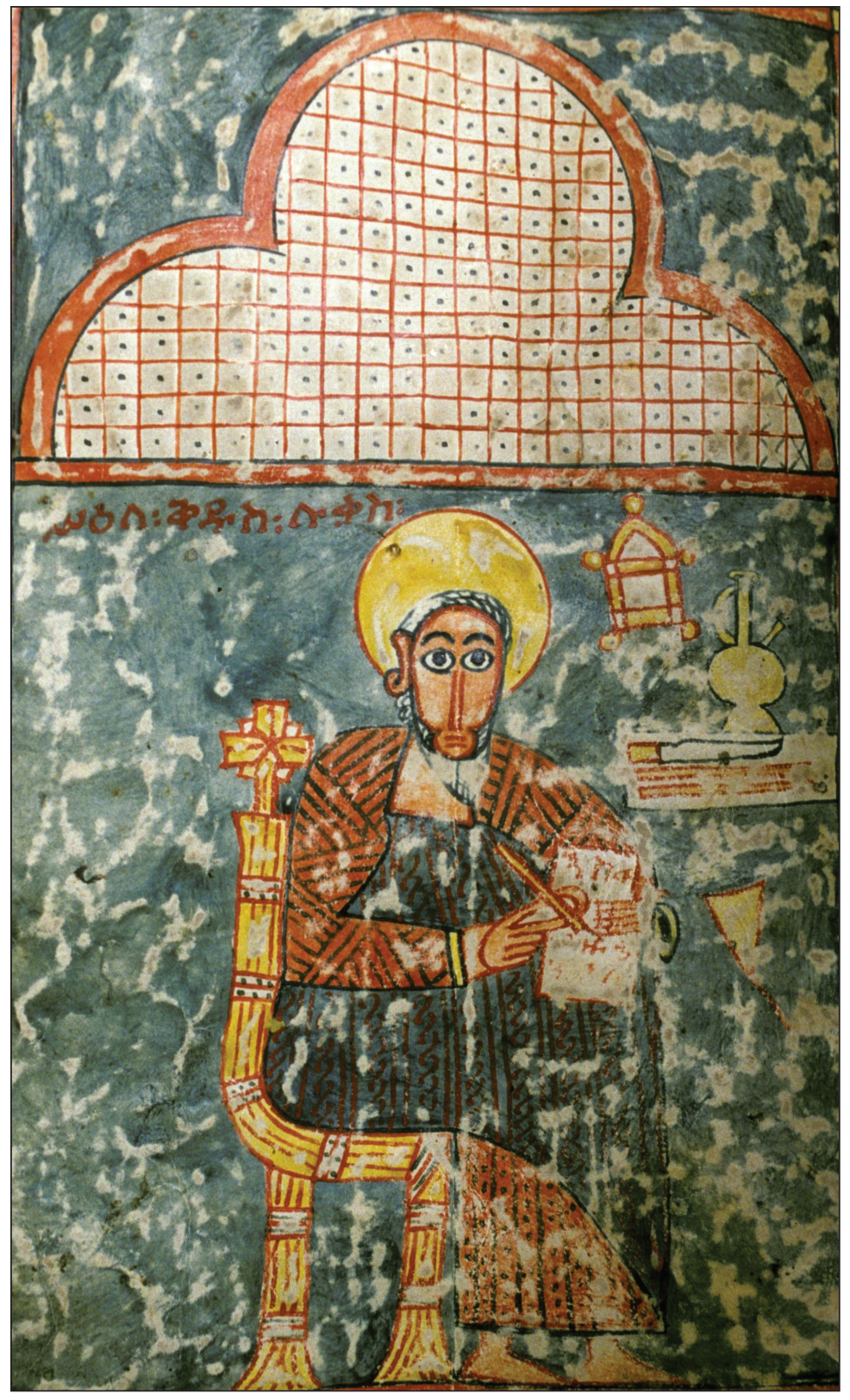

FIGURE 7. The Evangelist Luke. Gospel book from the monastery of Boru Śllase, $36 \times 32 \mathrm{~cm}$. (C) Stanislaw Chojnacki, courtesy of the DEEDS project. 
The writing instruments in the three portraits of Luke are arranged in a slightly different fashion, but they are clearly very similar. In all three cases, there is an ewer, an object that looks like a casket, with a triangularshaped lid and rounded finials, ${ }^{33}$ and a small rectangular-shaped table with reeds and a knife. In BSL there is one ink horn, whereas in NWM and DTM there are two ink horns. Also absent in BSL is the small squareshaped element-which could represent a piece of parchment or a tablet used for supporting the parchment-visible in the other two examples.

Finally, it is worthwhile noting that in all three miniatures, the inscription that identifies Luke is placed below the lower-left corner of a frame that divides the portrait from the trefoil arch with a checkered pattern. The intersections of this frame are marked by small squares, though in DTM and NWM the corners are filled with stylized elements that are different

33 This detail originally represented a lectern; this is one of several cases of corruption that appear in illuminated Ethiopic Gospel books of the early Solomonic period, as I illustrate in a forthcoming study on the topic. In in this context, let it suffice to note that the closest parallels to the seated type in the Ethiopian tradition are to be found not so much in early Greek and Syriac manuscripts, such as the Codex purpureus Rossanensis (Rossano, Museo Diocesano e del Codex, fol. 121r) or the Rabbula Gospels (Florence, Biblioteca Mediceo Laurenziana, cod. Plut. I, 56, fol. 9v), but in Armenian and post-iconoclastic Byzantine manuscripts. More sporadically, there are also points of contact with the Latin and Georgian traditions. For the relationship with Greek manuscripts, compare the Ethiopian miniatures with, for instance, London, British Library, Add MS 5111, fol. 12r; Vatican, Biblioteca Apostolica Vaticana, Pal. Gr. 220, fol. 99r, and Vat. Gr. 364, fols. 84r, 131r; New York, The Morgan Library \& Museum, MS M.639, fol. 218r; Baltimore, The Walters Art Museum, MS W.527, fol. 1v; MS W.530.A, fol. 1r; and MS W.531, fol. 60r; Vienna, Österreichische Nationalbibliothek, Cod. Suppl. Gr. 52, fol. 13v; and Cleveland, Cleveland Museum of Art, 1942.1511. See also the Armenian Gospels of Trebizond in Mekhitarist Congregation, San Lazzaro, n. 1400/108, fol. 101v. Given the close ties between Ethiopian and Alexandrian churches, it is also worth investigating Copto-Arabic Gospels further, on which see L.-A. Hunt, "Illustrating the Gospels in Arabic: Byzantine and Arab Christian Miniatures in Two Manuscripts of the Early Mamlūk Period in Cambridge," in The Bible in Arab Christianity, ed. D. R. Thomas, History of Christian-Muslim Relations 6 (Leiden: Brill, 2007), 315-50; and L.-A. Hunt, "An Icon and a Gospel Book: The Assimilation of Byzantine Art by Arab Christians in Mamluk Egypt and Syria," in Studies in Coptic Culture: Transmission and Interaction, ed. M. F. Ayad (Cairo: American University in Cairo Press, 2016), 93-116, with additional bibliography. 
from each other and that are absent in BSL. Yet, as I have argued elsewhere, ${ }^{34}$ Ethiopian artists appear to have been very unsystematic in the use of such decorative elements.

In light of the similarities listed above, it seems evident that the three portraits of Luke are closely related to each other. Indeed, in the case of DTM and NWM, the two miniatures are so close that it is possible that they are based on the same model. Additional supports for this opinion comes from the fact that all the surviving scenes from NWM are found in BSL and that the miniatures from these two manuscripts show a strong degree of iconographic affinity. This is particularly evident in the representations of the Nativity, the Entombment, and the Resurrection of Christ, but less so in the case of the Ordeal of the Bitter Water. ${ }^{35}$ It is unfortunate that only two portraits of Evangelists and two pages of the Letter of Eusebius to Carpianus survive in DTM, for, judging on what survives, the miniatures in this latter manuscript are even more closely related to NWM than those in BSL, though whether DTM ever included a Christological cycle is at present impossible to ascertain.

In the depiction of the Entombment ${ }^{36}$ in NWM (see fig. 4), the caption placed on the frame that separates the scene from the trefoil simply states: "How Joseph and Nicodemus shrouded Him." ${ }^{37}$ The miniature shows the two men bent forward in the act of placing Christ's body in the tomb in front of them. The Entombment in BSL (fig. 8) has much in common with the depiction in NWM in terms of arrangement and iconography: Joseph and Nicodemus bend forward and wrap their arms around the shrouded

34 In "Towards a Comparative Framework for Research on the Long Cycle in Ethiopic Gospels: Some Preliminary Observations,” Aetbiopica 20 (2017): 70-105.

35 The Ordeal of the Bitter Water in NWM has already been discussed in Chojnacki, The Theme of the Bitter Water, 15, so there is little need to analyze it further in the context of this study.

36 For a more detailed study of the iconography of the Entombment in early Solomonic Ethiopian illumination, see J. Gnisci, "Shrouding the Divine: Observations on the Iconography of the Entombment of Christ in Ethiopian Illumination of the Fourteenth and Early Fifteenth Centuries," Orientalia Christiana Periodica 81, no. 2 (2015): 473-92, with further bibliography.

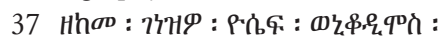




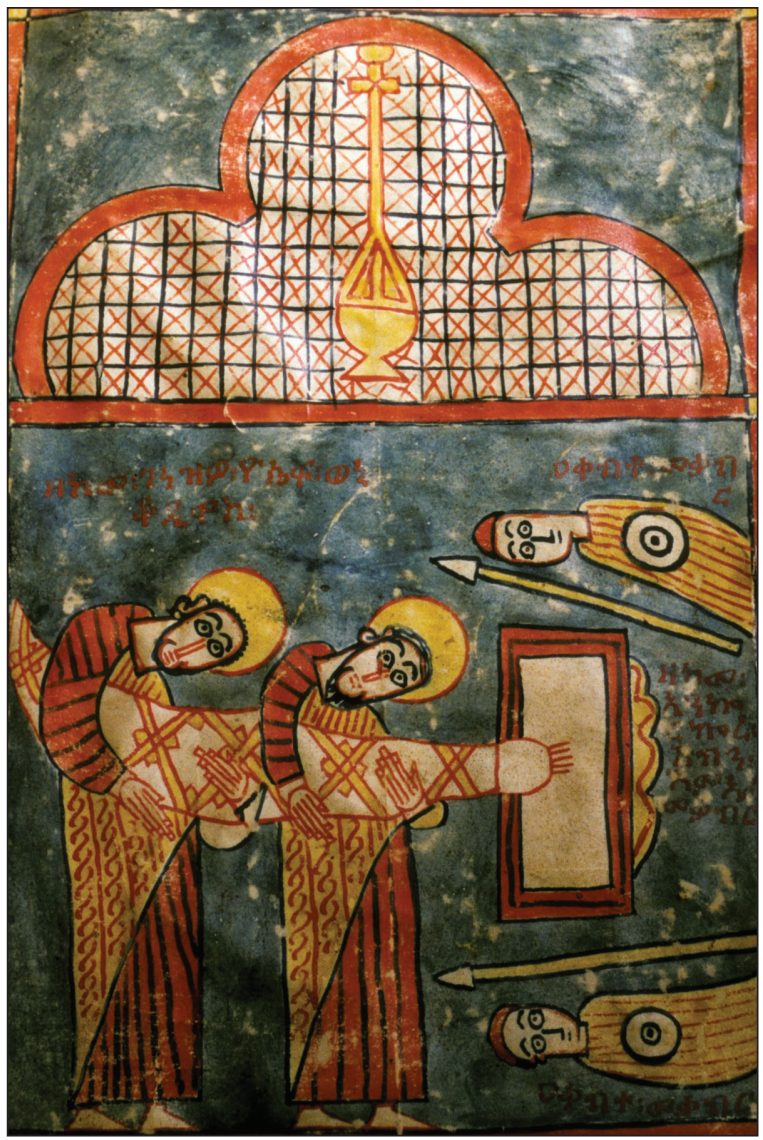

FIGURE 8. The Entombment. Gospel book from the monastery of Boru Śəllase, $36 \times 32 \mathrm{~cm}$. (C) Stanislaw Chojnacki, courtesy of the DEEDS project.

body of Christ; their clothes have similar folds; the cross-like ornaments on the shrouds are almost identical, as is the unusual knot at the top; the curtain of the tomb is placed to the right and is similarly rendered; the two guards, respectively depicted above and below the tomb, wear a simple tunic with straight lines, hold a white shield with a dotted circle at its center, and have a small pointed hat and a spear; and their feet and arms are not visible. The only two significant differences between the two versions of the 
Entombment are that in BSL the guards are identified by captions and that they have their heads turned toward Joseph and Nicodemus. ${ }^{38}$

Similar observations could be made regarding the two miniatures in which the Resurrected Christ appears to Peter, John, and Mary Magdalene. However, a comparison between the miniature of the Nativity in BSL and that in NWM presents us with a far more interesting phenomenon. ${ }^{39}$ The Nativity in BSL (fig. 9) features most of the iconographic elements visible already in the Gospels of Iyäsus Mó (IM) ${ }^{40}$ which preserve the earliest known version of this theme in Ethiopian manuscript illumination (fol. 18r; fig. 10). In both miniatures, we see the reclining Virgin with Joseph to her right and Salome to her left, the infant Christ in the manger with the ox and the ass near him, and three shepherds. In IM, the shepherds follow a star, a detail that is absent in BSL, and do not have sheep as they do in BSL. ${ }^{41}$ Also in BSL Joseph turns his back to the Virgin, an unusual variant, and there is no division between the shepherds and the Virgin. ${ }^{42}$

38 This latter detail is of interest for reconstructing the evolution of this version of the Entombment in Ethiopia. In fact, in BSL, the guards do not have feet because the bottom of their robes touches the frame.

39 For a more general discussion of the Nativity in Ethiopian art, see S. Chojnacki, "The Nativity in Ethiopian Art," Journal of Etbiopian Studies 12, no. 2 (1974): 11-56.

40 Däbrä Hayq Hsțifanos, produced in 1280/81. On this manuscript, see Taddesse Tamrat, “The Abbots of Däbrä-Hayq 1248-1535,” Journal of Etbiopian Studies 8, no. 1 (1970): 90-92; Getatchew Haile and W. F. Macomber, A Catalogue of Etbiopian Manuscripts Microfilmed for the Etbiopian Manuscript Microfilm Library, Addis Ababa and for the Hill Monastic Manuscript Library, Collegeville, vol. 5: Project Numbers 1501-2000 (Collegeville, MN: Hill Monastic Manuscript Library, 1981), 293-301; Zuurmond, Novum Testamentum, Part II, 55-56; Balicka-Witakowska, Crucifixion, 123-24; M.-L. Derat, Le domaine des rois éthiopiens (12701527): espace, pouvoir et monachisme (Paris: Publications de la Sorbonne, 2003), 139-41; and C. Bosc-Tiessé, "Sainteté et intervention royale au monastère Saint-Etienne de Hayq au tournant du XIIIe et du XIVe siècle: L'image de Iyasus Mo'a dans son Evangile,” Oriens Christianus 94 (2010): 199-227, with further bibliography.

41 The presence or absence of the sheep does not appear to be based on the use of a different model. Rather, it seems like Ethiopian painters did not consider this iconographic detail fundamental and felt free to include or exclude it; see, for instance, Chojnacki, Nativity, 15-16. 42 As the shepherds are generally separated by a line in most versions of this theme in Gospels from the late fourteenth to the mid-fifteenth centuries, we may assume that such a division was present in the model from which most version of this theme stem. 


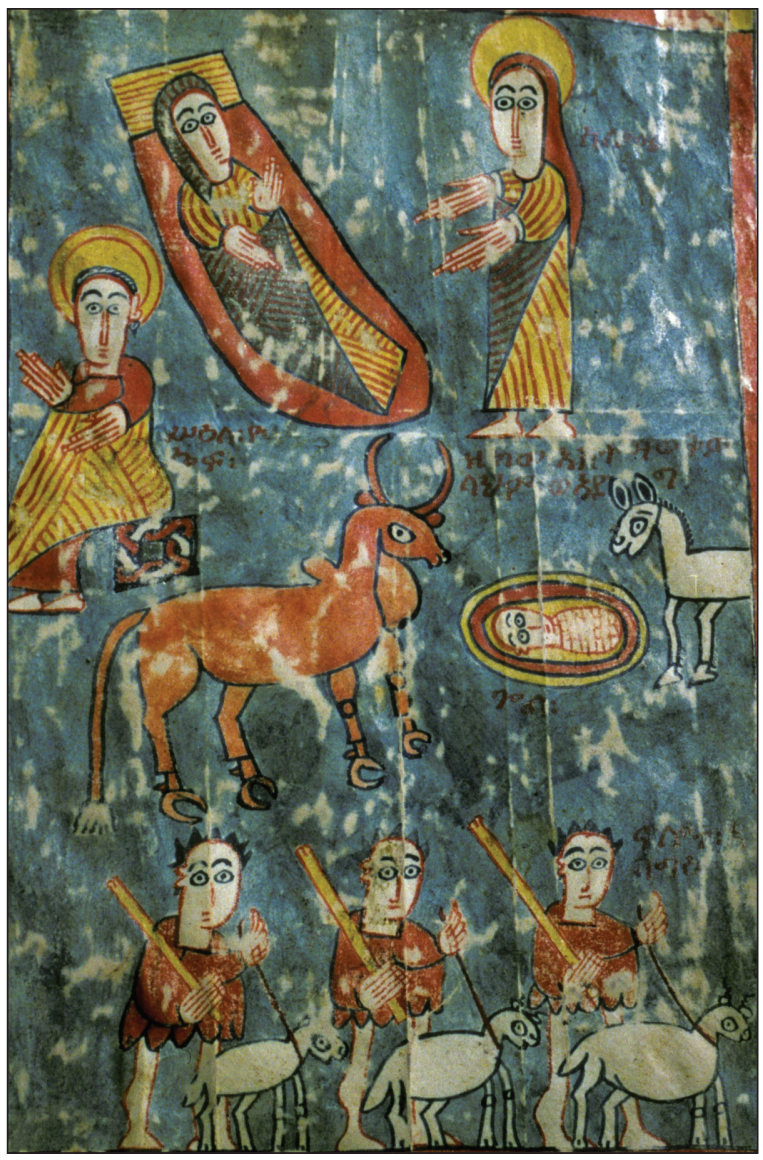

FIGURE 9. The Nativity. Gospel book from the monastery of Boru Śəllase, $36 \times 32 \mathrm{~cm}$. (C) Stanislaw Chojnacki, courtesy of the DEEDS project.

Nevertheless, the principal difference between the two representations of the Nativity is that the manger with Christ is placed between the Virgin and the shepherds in BSL rather than above her as in IM. This is an unusual variant, as the manger is generally placed either above or next to the Virgin. ${ }^{43}$ This difference does not necessarily imply that the Nativity in BSL belongs

43 E.g., in ZG, fol. 7v. See Skehan, An Illuminated Gospel, pl. 2, for a reproduction. 


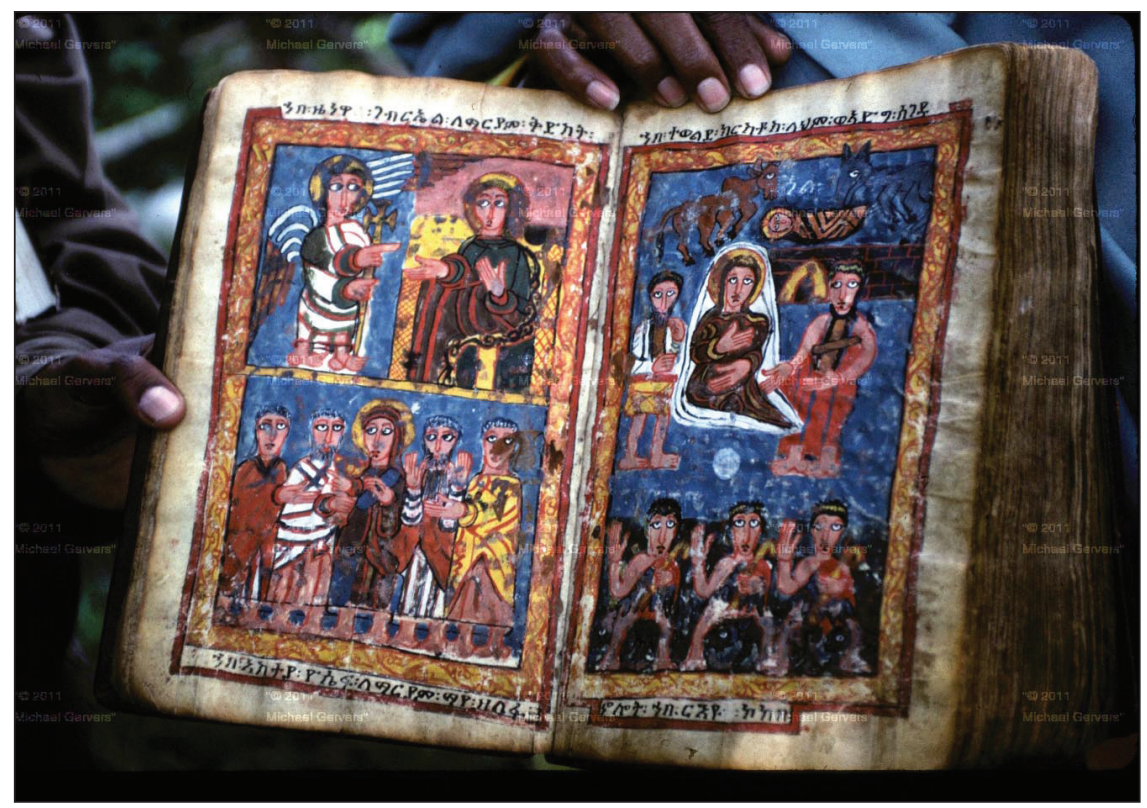

FIGURE 10. The Annunciation, the Ordeal of the Bitter Water, and the Nativity. Gospels of Iyäsus Mo'a from the monastery of Däbrä Hayq ヨsțifanos, $27.5 \times 17.5 \mathrm{~cm}$. (C) Michael Gervers.

to a different iconographic family; rather, it is possible that an inexperienced painter, having started outlining from left to right and finding that he had taken up too much space for the portraits of Joseph, Mary, and Salome, simply moved the detail of the manger and child below the other three figures. ${ }^{44}$ An alternative explanation is that the artist responsible for BSL, or for the model followed by BSL, decided to place the manger at the center of the page to give greater prominence to the figure of the Christ-Child. ${ }^{45}$

44 Another possibility is that a vertical layout was imposed by the format of the manuscript, but I know of no illuminated Gospels from this period in which the format would impose such a variant.

45 On the use of unusual iconographic formulas as a reflection of religious beliefs or liturgical customs in Ethiopian art, see J. Gnisci, "The Liturgical Character of Ethiopian Gospel Illumination of the Early Solomonic Period: A Brief Note on the Iconography of the Washing of the Feet," in Aethiopia Fortitudo Ejus, 253-75. 
Most interestingly, we find the same solution adopted in the Nativity in NWM (see fig. 1, left), in which the manger ${ }^{46}$ is placed below the threefigure group of Joseph, ${ }^{47}$ Mary, ${ }^{48}$ and Salome, ${ }^{49}$ and above a group of two figures with sticks identified as the "Shepherds of Sheep." ${ }^{50}$ At first, the presence of five figures bearing gifts, and identified as "the Magi" by a caption, ${ }^{51}$ in the lower-right portion of the miniature would seem to preclude any possible relationship between this version of the Nativity and the one found in BSL. However, on closer scrutiny, the two miniatures agree in so many respects (the poses, attire, and spiky hair of the shepherds; the hook-shaped hooves and tail of the ox; the donkey cut in half by the frame; the gesture of Salome and the folds of her garments; the chair on which Joseph is seated) that they must descend from a common prototype.

The most likely explanation, then, is that the Magi are an addition to the core model and that the artist who painted the NWM Nativity decided to compress two scenes-namely, the Adoration of the Magi and the Nativityinto one page..$^{22}$ In order to achieve this, he had to decrease the number of shepherds from three to two and considerably reduce the size of the ox and ass, which in fact, although much smaller than the two animals in BSL, are almost identical to them. The compression of two themes into one page is a

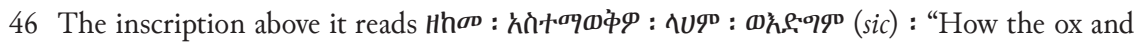
the ass warmed Him."

47 The caption next to Joseph is damaged but still legible as $\left[\mu_{0}\right]$ ก : prís: : "Image of Joseph.”

48 It seems likely that Mary was also originally identified by a caption.

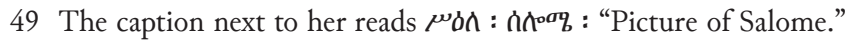

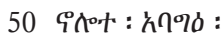

51 ถ่าก : ถ่าล :

52 Representations of the Magi and the Nativity generally occupy separate pages in Ethiopian Gospel illumination of the late thirteenth to the early fifteenth centuries, though during the fifteenth century, the two scenes are more frequently combined. For a more detailed discussion on this topic, see J. Gnisci and R. Zarzeczny, “They Came with their Troops Following a Star from the East': A Codicological and Iconographic Study of an Illuminated Ethiopic Gospel," Orientalia Christiana Periodica 83, no. 1 (2017): 127-89, with further bibliography. On the traditions relating to the Magi in Ethiopian literature, see W. Witakowski, "The Magi in Ethiopic Tradition," Aethiopica 2 (1999): 69-89. 
phenomenon that occurs already in IM and that seems to have increased from the turn of the fifteenth century onward, though the two scenes placed on a page are generally separated by a frame rather than merged as they are in NWM. ${ }^{53}$ This phenomenon occurs also in BSL, in which the Annunciation and the Ordeal of the Bitter Water are painted on the same page (fol. 8v)..$^{54}$ Furthermore, if, as seems likely, the canon tables and miniatures in NWM come from the same manuscript, then the compression of two scenes in the Nativity finds a parallel in the compression of the canon tables into eight rather than ten pages.

The last point to be considered is whether it is possible to associate NWM with a particular region or area of Ethiopia on the basis of its style. In the catalog of an exhibition of Ethiopian art held at the Walters Art Museum, Griffith Mann, in his description of W.839 (see fig. 4), claims that it may have been "made in the Lake Tana region as it shares important stylistic connections with manuscripts produced in the monastic communities of the lake's islands." ${ }^{55}$ It is not infrequent to find similar remarks in the literature about Ethiopian art, but such observations seem to have little or no foundation when one deals with early Solomonic illumination.

It has been seen above that, from a stylistic and iconographic point of view, DTM and BSL are very close to NWM. However, the monastery of Däbrä Tä’amina, in which DTM is kept, is situated about fifty kilometers northwest of Mäqälä. Boru Śəllase, on the other hand, is situated approximately ten kilometers north of the town of Däse. In other words, neither of the two monasteries is close to Lake Tana. It is true that the ownership notes in DTM (fol. 191r) ${ }^{56}$ and BSL (fols. 1r, 3r) are clearly posterior, thus

53 E.g., ZG, fol. 11v; and a Gospel manuscript from Gäbrä Krəstos, dated to 1476, published in S. Chojnacki, Christ's Resurrection in Ethiopian Painting, Orientalia Christiana Analecta 282 (Rome: Pontificio Istituto Orientale, 2009), 28-29.

54 For a reproduction, see Chojnacki, The Theme of the Bitter Water, pl. III.

55 C. Griffith Mann, "The Role of the Illuminated Manuscript in Ethiopian Culture," in Ethiopian Art: The Walters Art Museum, ed. D. E. Horowitz (Chailey: Third Millennium, 2001), 98.

56 This note was photographed by Michael Gervers, whom I thank for sharing the document. 
making it difficult to ascertain whether they were always kept in what is their current location. But it is precisely because we cannot pinpoint with certainty the scriptorium, or scriptoria, ${ }^{57}$ in which these manuscripts were made, and because they are found in different parts of the country, that we should be wary of associating a particular style of painting with a particular region. ${ }^{58}$

57 In fact, it is just starting to be debated whether it is appropriate to use the term "scriptorium" in the context of Ethiopia; for some preliminary observations, see A. Bausi, E. BalickaWitakowska, D. Nosnitsin, and C. Bosc-Tiessé, "Ethiopic Codicology," in Comparative Oriental Manuscript Studies: An Introduction, ed. A. Bausi et al. (Hamburg: COMSt, 2015), 154-14, esp. 169. With respect to the study of such problems, the fact that historians of Ethiopian art are only beginning to address them highlights that this field is still very much at an early stage of development. In comparison, Byzantinists have been tackling similar issues for decades; see, for instance, J. C. Anderson, "Cod. Vat. Gr. 463 and an Eleventh-Century Byzantine Painting Center,” Dumbarton Oaks Papers 32 (1978): 175-96.

58 This does not rule out the possibility of associating a style with a monastic network, as done for instance by Marilyn Eiseman Heldman, "An Ēwosțāthian Style and the Gundā Gundē Style in Fifteenth-Century Ethiopian Manuscript Illumination," in Proceedings of the First International Conference on the History of Ethiopian Art (London: Pindar Press, 1989), 5-14; and M. Gervers, "Finding the Ewosțateans," in Ecclesiastic Landscape of North Ethiopia, ed. D. Nosnitsin (Wiesbaden: Harrassowitz Verlag, 2013), 49-60. 


\section{LisT OF MANUSCRIPTS CITED}

Baltimore, Walters Art Museum

W.527: 374 n. 33

W.530.A: 374 n. 33

W.531: 374 n. 33

W.838: 358, 360, 362, 362 fig. 5, 364

table 1, 365-77, 380-2

W.839: 358, 360, 361 fig. 4, 362, 365-77, 370 n. $29,380-2$

W.840: 358, 360, 360 fig. 3, 365-77, 370

n. $29,380-2$

\section{Boru Śəllase Monastery}

Gospels of Boru Śllase: 367, 367 n. 17, 369-72, 373 fig. 7, 374-82, 376 fig. 8, 378 fig. 9

Cambridge, MA, Harvard University, Houghton Library MS Eng. 1014: 306, 316-17, 317 n. 38, 320, 330

MS Richardson 28: 441 n. 12, 442 n. 14

Chandigarh, Punjab University, AC Joshi

Library

MS 1428: 292 n. 39

MS M-105: 292 n. 39

Cleveland, Cleveland Museum of Art 1942.1511: 374 n. 33

Däbrä Hayq Hsțifanos Monastery

Gospels of Iyäsus Móa: 377-78, 377 n. 40, 379 fig. 10, 381

Däbrä Tä’amina Monastery

Gospels of Däbrä Tä’amina: 367, 367 n. 18, 369-72, 372 fig. 6, 374-75, 381-82
Dublin, Trinity College Library

MS 58: 366 n. 10

Edinburgh, National Library of Scotland MS Hawthornden 2064: 306, 318, $318 \mathrm{n}$. $41,320-21,330-31$

Florence, Biblioteca Medicea Laurenziana Plut. 1.56: 374 n. 33, 422

The Hague, National Library of the

Netherlands

MMW 10 A 19: 412, 412 n. 57

Jaipur, Maharaja Sawai Singh II Museum MS 2440.28: 288, 288 n. 33

Jaipur, Rajasthan Oriental Research Institute MS 2165: 296

Jodhpur, Rajasthan Oriental Research

Institute

MS 24778: 294 n. 42

MS 26094: 286-87

MS 26334: 277 fig. 3

MS 26579: 296; 297 fig. 6

MS 27518: 284 fig. 4

Leiden, Rijksuniversiteitbibliothek

BPL 108: 435

BPL 111: 435

Scaliger 38: 435

London, British Library

MS 2 B I: 398, 399 fig. 10, 407, 410

MS Add. 5111: 374 n. 33

MS Add. 62925: 403-4, 405 fig. 13

MS Cotton Nero A.x: 383-90, 383 n. 1, 384 n. 3, 388 fig. 1, 389 fig. 2, 390 fig. 3, 
391 fig. 4, 391 fig. 5, 392 fig. 6, 392-407, 394 fig. 7, 395 fig. 8, 401 fig. 11, $406 \mathrm{f}$ ig. 14,408 n. 48, 408 n. 49, 409-20, 411 fig. 15

MS Egerton 1070: 401 n. 32

MS Harley 364: 306, 317, 317 n. 39, 320

MS Harley 966: 305

MS Harley 967: 302, 306

MS Harley 2292: 306

MS Harley 5903: 311 n. 30

MS Harley 5906b: 311 n. 30

MS Harley 5908: 311 n. 30

MS Harley 5909: 311 n. 30

MS Harley 5910: 311 n. 30

MS Harley 5914: 311 n. 30

MS Harley 5915: 311 n. 30

MS Harley 5916: 311 n. 30

MS Harley 5917: 311 n. 30

MS Harley 5918: 311 n. 30

MS Harley 5919: 311 n. 30

MS Harley 5920: 311 n. 30

MS Harley 5921: 311 n. 30

MS Harley 5922: 311 n. 30

MS Harley 5923: 311 n. 30

MS Harley 5924: 311 n. 30

MS Harley 5925: 311 n. 30

MS Harley 5926: 311 n. 30

MS Harley 5927: 311 n. 30

MS Harley 5928: 311 n. 30

MS Harley 5929: 311 n. 30

MS Harley 5930: 311 n. 30

MS Harley 5931: 311 n. 30

MS Harley 5932: 311 n. 30

MS Harley 5933: 311 n. 30

MS Harley 5934: 311 n. 30

MS Harley 5935: 311 n. 30

MS Harley 5936: 311 n. 30

MS Harley 5937: 311 n. 30

MS Harley 5938: 311 n. 30

MS Harley 5939: 311 n. 30

MS Harley 5940: 311 n. 30

MS Harley 5941: 311 n. 30

MS Harley 5942: 311 n. 30
MS Harley 5943: 311 n. 30

MS Harley 5944: 311 n. 30

MS Harley 5945: 311 n. 30

MS Harley 5946: 311 n. 30

MS Harley 5947: 311 n. 30

MS Harley 5948: 311 n. 30

MS Harley 5949: 311 n. 30

MS Harley 5950: 311 n. 30

MS Harley 5951: 311 n. 30

MS Harley 5952: 311 n. 30

MS Harley 5953: 311 n. 30

MS Harley 5954: 311 n. 30

MS Harley 5956: 311 n. 30

MS Harley 5957: 311 n. 30

MS Harley 5958: 311 n. 30

MS Harley 5959: 311 n. 30

MS Harley 5960: 311 n. 30

MS Harley 5961: 311 n. 30

MS Harley 5962: 311 n. 30

MS Harley 5963: 311 n. 30

MS Harley 5964: 311 n. 30

MS Harley 5965: 311 n. 30

MS Harley 5966: 311 n. 30

MS Harley 5967: 311 n. 30

MS Harley 5968: 311 n. 30

MS Harley 5969: 311 n. 30

MS Harley 5970: 311 n. 30

MS Harley 5971: 311 n. 30

MS Harley 5972: 311 n. 30

MS Harley 5973: 311 n. 30

MS Harley 5974: 311 n. 30

MS Harley 5975: 311 n. 30

MS Harley 5976: 311 n. 30

MS Harley 5977: 311 n. 30

MS Harley 5978: 311 n. 30

MS Harley 5986: 311 n. 30

MS Harley 5987: 311 n. 30

MS Harley 5988: 311 n. 30

MS Harley 5989: 311 n. 30

MS Harley 5990: 311 n. 30

MS Harley 5991: 311 n. 30

MS Harley 5992: 311 n. 30

MS Harley 5993: 311 n. 30 
MS Harley 5994: 311 n. 30

MS Harley 5995: 311 n. 30

MS Harley 5996: 311 n. 30

MS Harley 5997: 311 n. 30

MS Harley 5998: 311 n. 30

MS Harley 6795: 306

MS Royal 6 E VI: 396, 396 n. 21

MS Royal 6 E VII: 396, 396 n. 21

MS Royal 16 G VI: 403, 403 n. 40, 404

fig. 12

MS Royal 19 B XV: 393 n. 19

MS Sloane 885: 311 n. 30, 312

MS Sloane 1044: 311 n. 30

MS Sloane 1086: 311 n. 30

MS Sloane 1983: 311 n. 30

London, Lambeth Palace Library

MS Arc.L.40.2/E.23: 307

MS Arc.L.40.2/E.25: 307

MS Arc.L.40.2/E.64: 308 n. 22

MS Sion L40.2/E24: 307-8, 309 fig. 1, 312-15, 316 fig. 2, 318-19, 321-29, 325

fig. 3, 328 fig. 4, 331-33, 331 n. 50, 332 fig. 5

London, University College London

Library

MS Ogden 7: 305 n. 13

Los Angeles, J. Paul Getty Museum

MS 33: 413-14, 413 fig. 16

MS 89: 370-71, 370 n. 31

Manchester, John Rylands Library

Hindustani MS 1: 275 fig. 2

Rylands French 142: 406-7, 407 n. 43

Maynooth, Russell Library

RB36: 431-32, 432 fig. 1, 433 fig. 2, 436, 438

Mehakelegnaw, Abba Garima Monastery

Gärima I: 363, 363 n. 4, 363 n. 5, 366

n. $10,367-68$

Gärima II: 363 n. 4, 363 n. 5, 366, 366

n. 10,367
Gärima III: 363, 363 n. 4, 363 n. 5, 366, 366 n. 10, 367-68

Naples, Università degli Studi di Napoli

L'Orientale

MS ARA 30: 340 n. 14, 342 n. 21, 343 n.

24, 344 n. 28,347 n. 37,356

MS ARA 50: 340 n. 14, 340 n. 15, 342 n.

21, 344-45, 344 n. 27, 345 n. 29, 345 n.

30, 345 n. 31,347 n. 37,356

MS ARA 51: 356

MS ARA 71: 340 n. 14, 343 n. 24, 347 n.

37, 356

MS ARA 93: 340 n. 15, 343 n. 24, 356

MS ARA 259: 345 n. 30, 345 n. 31, 347

n. 37,356

MS ARA [no shelfmark] "Kitāb al-jawāhir al-muntaqāt”: 345 n. 30, 345 n. 31, 347 n.

37, 356

MS ARA [no shelfmark] "Fiqh Ibāḍite": 347 n. 37,356

New York, Metropolitan Museum of Art 57.185.3: 425-26, 427 fig. 2

New York, Morgan Library and Museum MS M.639: 374 n. 33

MS M.828: 363 n. 4, 367, 367 n. 15, 369

n. 28,378 n. 43,381 n. 53

MS M.1078: 396, 397 fig. 9, 409 n. 52

MS M.1112: 425-26, 427 fig. 2

Newark, NJ, Newark Museum

Coll. 96.46.1: 357-58, 358 fig. 1, 365-77, 375 n. $35,380-82,380$ n. $46-51$

Coll. 96.46.2: 357-58, 359 fig. 2, 360, 362, 364 table 1, 365-77, 380-82

Oxford, Bodleian Library

MS Ashmole 792: 306, 312 n. 32

MS. Eng. poet. a. 1: 398, 398 n. 28

MS Junius 11: 396, 396 n. 20

Oxford, Queen's College Library

MS 251: 306, 313, 317-18, 318 n. 40, $320,330,333$ 


\section{8 | Journal For Manuscript Studies}

Paris, Bibliothèque Nationale

MS Éthiopien 32: 365 n. 7, 367-68, 368 n. 18

MS. lat. $964: 435,435$ n. 6

MS. lat. 4892: 435

MS. lat. 5019: 435

MS. lat. 9435: 435

Philadelphia, University of Pennsylvania

MS Codex 85: 442-69, 442 n. 15, 443

n. 16,443 n. 17,443 n. 20,444 n. 21,444

n. 22

MS Codex 736: 441-42, 441 n. 12, 442

n. 14

MS Coll. 390, Item 42: 483

MS Coll. 390, Item 178: 480

MS Coll. 390, Item 292: 484 n. 28

MS Coll. 390, Item 497: 482 n. 25

MS Coll. 390, Item 533: 483, 483 fig. 4

MS Coll. 390, Item 890: 474 n. 10

MS Coll. 390, Item 893: 474 n. 10

MS Coll. 390, Item 896: 474 n. 10

MS Coll. 390, Item 1136: 479 n. 18

MS Coll. 390, Item 1334: 479 n. 19

MS Coll. 390, Item 1567: 482

MS Coll. 390, Item 1783: 485

MS Coll. 390, Item 2053: 484 n. 28

MS Coll. 390, Item 2172: 480

MS Coll. 390, Item 2615: 480, 481 fig. 3

MS Coll. 390, Item 2660: 480

MS Coll. 390, Item 2670: 475 n. 13

MS Coll. 390, Item 2671: 475 n. 13

MS Coll. 390, Item 2672: 475 n. 13

MS Coll. 390, Item 2673: 475 n. 13

MS Coll. 390, Item 2674: 475 n. 13

MS Coll. 390, Item 2675: 475 n. 13

MS Coll. 390, Item 3020: 474

MS Coll. 390, Item 3045: 483

MS Indic 2: 476 n. 15
MS Indic 6: 476 n. 15

MS Indic 10: 274 fig. 1

MS Indic 26: 475 n. 13

MS Indic 28: 275 n. 15

Rossano, Rossano Cathedral, Diocesan

Museum

GA 042: 374 n. 33,422

Šemazānā, Akkala Guzāy, Däbrä Libanos

Monastery

Gospel of Däbrä Libanos: 365 n. 6

Təgray, Church of Qärsäbär Mika’el

Gospels of Qärsäbär Mika’el: 371 n. 32

Vatican City, Biblioteca Apostolica Vaticana

Pal. Gr. 220: 374 n. 33

Vat. Gr. 364: 374 n. 33

Venice, San Lazzaro, Mekhitarist Library

MS 1400/108: 374 n. 33

Vienna, Österreichische Nationalbibliothek Cod. Suppl. Gr. 52: 374 n. 33

Washington, D.C., U.S. Library of

Congress

MS 1-85-154.77: 276 n. 16

Yerevan, Matenadaran

MS 238: 422 n. 4

MS 974: 423, 424 fig. 1, 425

MS 2877: 422 n.4

MS 2930: 422 n. 4

MS 3784: 423 n.6

MS 4813: 423 n.6, 426, 428 fig. 3, 429

MS 4818: 422 n. 4

MS 7456: 422 n. 4

MS 7736: 422 n. 4

MS 9423: 422 n.4

MS 10780: 422 n.4 